\title{
Satsang, A Contemporary Religion of Convergence
}

\author{
Rajarshi Roy ${ }^{1}$
}

${ }^{1}$ (SPR, a voluntary role in Satsang)B.E.(Mech), M.B.A.(Finance)Senior Member, Satsang UK Senior IT Consultant London

\section{ARTICLE INFO}

\section{Keywords:}

Convergence,

Conversion, Initiation,

Religion, Living Ideal

\begin{abstract}
Purpose of this study is to identify the similarities in beliefs, traditions, and rituals of all the existing religions or religious practices of the world and explore the possibilities of religious convergence. The study found that although there are many similarities in the principles of the major religions in the world none of the old and existing religions offer religious convergence where a union of existing religions is possible. Satsang, a contemporary religion founded by Sree Sree Thakur Anukulchandra (1888-1969), a prominent philanthropist and one of the greatest philosophers of recent times, supports convergence. This paper explained the importance of initiation in the creed of a superior ideal in each of the major religions. It has also examined in detail about how people from any faith, race or religion can practice the principles of Satsang doctrine along with existing religious practices to accomplish the spiritual quests of individuals.
\end{abstract}

\section{Introduction}

The term 'Religious Convergence' signifies a religious platform where all the existing and old religious believers and practitioners can perform unique spiritual practices belong to each religious group, under one platform without diluting individual identities to fulfil individuals' spiritual quest. In other word it can be defined as union of all religions in one platform.

\section{Similarities in Principles in Major Religions in the World}

When one looks at all the major world religions, it is evident that that they are more similar than dissimilar in terms of their spiritual quest, the path of discipleship and goal of achieving holiness. When we look at Christianity, Judaism, Islam, Hinduism, Buddhism, Taoism and other native religions, we can draw out the following major points of convergence:

\footnotetext{
$\square$ Corresponding Author E-Mail Address: RRoy.SatsangUK@yahoo.co.uk
} 
- In all of them the aim of the spiritual quest is one; union with God and union with everyone and everything else. There are different disciplines, different ways of understanding God, and different ways of understanding life, but all these great spiritual traditions ultimately seek the same thing, union with the divine and, through that, peace with all objects, animate and inanimate in the entire creation.

- In all the great spiritual traditions compassion has been shown as the path to union with God. What each religion ultimately strives to achieve is a heart that is properly shaped in compassion and wisdom. Then, and only then, are worship, dogma, and justice done correctly.

- In every great spiritual tradition, the route to compassion and union with God is paradoxical, such that we have to lose ourselves to find ourselves, die to come to life, and give so as to receive. In every major spiritual tradition, we are taught that we cannot experience joy, delight, and happiness by actively pursuing them. These mental states are always a by-product of something else, namely, of trying to create joy, delight, and happiness for someone else. Every great spiritual tradition would be at ease with the Prayer of St. Francis: Affirming that in giving we receive, in consoling others we are consoled, and in trying to understand others we are understood.

- $\quad$ Every great spiritual tradition is clear that spiritual progress requires hard discipline and some painful renunciations, that the road-more-travelled won't get you home. The gate to heaven is always the narrow one, the one that requires discipline and renunciation. Indeed the word "discipleship" comes from the word "discipline". When Hinduism and Buddhism speak of different kinds of "yoga" they are simply referring to various forms of discipline (from which we take our reduced sense of the word "yoga").

- $\quad$ Every great spiritual tradition tells us that the spiritual quest is a life-long journey with no short-cuts, no quick paths, no hidden secrets, and no appeal to privilege that can bypass the discipline and renunciation required. They also tell us that there are no exempt areas within the spiritual life and that there are no moral or psychological areas that we can ignore or write-off as unimportant. No great spiritual tradition lets us chose between personal integrity and social justice, personal holiness or political action. Every one of them tells us that both are non-negotiable.

- In every great spiritual tradition consolation and desolation, religious fervor and dark nights of the soul, both have an important role within the spiritual journey. Both provide a necessary, albeit very different, kind of nurturing. All traditions caution us not to identify progress only with consolation and fervor, just as all of them caution us not to make suffering, desolation, and dark nights an end in themselves. 
- What may seem surprising to some, is that all the great spiritual traditions downplay the importance of extraordinary phenomena within the spiritual journey. Visions, altered states of consciousness, mystical trances, ecstasies, miracles, and appearances by persons or forces from the other world, whether benign or malevolent, soothing or frightening, are all downplayed in every major tradition. These can be real and they can mark our lives, but they are not indicative of real growth and progress which, in all great traditions, take place within the ordinary bread-andbutter of life. In every major spiritual tradition, the essential things that God wants us to know are public, documented and available to all, All traditions make the distinction between public revelation (which is binding for everyone) and private revelations (which, though meaningful, are not binding for everyone and are not a revelation even inside of the life of the person to whom they are given.)

- All great spiritual traditions affirm that, while we are on the spiritual path, we will encounter great temptations and powerful demonic forces and that these need to be addressed and managed seriously. All of them caution against naiveté, especially naiveté regarding certain innate tendencies within our own make-up and within the dynamics of every crowd.

- $\quad$ Finally, all the major spiritual traditions agree that the spiritual journey will always partly be mystery. Just as the God we meet on this journey is ultimately ineffable, so too is the experience. In the end we may never find adequate words and concepts that describe what we experience along the journey. Hence all traditions caution strongly against ever thinking that our grasp of things is adequate, even remotely so.

\section{No Convergence Only Conversion}

All the great religious traditions agree: The road is narrow and hard and there are no short-cuts. But incidentally, religious convergence has not been exhibited by most of the religious practitioners in the world, rather seen Religious conversion.

Religious conversion can be observed as a very much impactful social phenomenon in the history of human civilisation. It can be defined as the adoption of religious beliefs that differ from the convert's previous beliefs. It involves adopting a new religious identity, or changing one's religious identity. Conversion requires internalization of the new belief system.

Historical and current incidents both teach us that people convert to a different religion for various reasons, including: active conversion by free choice due to a change in beliefs, secondary conversion, deathbed conversion, conversion for convenience and marital conversion, and forced conversion such as conversion by violence or charity. 
Conversion or affiliation for convenience is an insincere act; it may occur for various reasons such as a parent converting to enable a child's admission to a good school associated with a particular religion, a person adopting a religion more in keeping with the social class they aspire to be in or a person in an inter-religious marriage a spouse converting to the religion of the spouse.

Forced conversion is adoption of a different religion under duress. The convert may secretly retain the previous beliefs and continue, covertly, with the practices of the original religion, while outwardly maintaining the forms of the new religion. Over generations a family forced against their will to convert may wholeheartedly adopt the new religion.

\section{Sree Sree Thakur Anukulchandra and Satsang}

Sree Sree Thakur Anukulchandra (1888-1969), one of the greatest philosophers of modern times, the prophet of current age, the founder of the religion, Satsang, was a supreme spiritual Master and compassionate seer. The Realised Guide, Sree Sree Thakur Anukulchandra's philosophy is based on the Being and Becoming of every living creature on earth. His philosophy teaches individuals how to approach the life's problems in a balanced, dynamic, rationalistic and scientific way. In His immense compassion, to help every ordinary people to attain spiritual enlightenment in everyday life affairs including materialistic progress, Sree Sree Thakur Anukulchandra has lifted spirituality from the scriptures and made it relevant to our daily life with the formula of practicing simple but meaningful Ideal centric life. Sree Sree Thakur has defined someone's Ideal as follows:

"Ideal means - who enrich the past, enliven the present and enlighten the future. "

This Ideal person is the summation of all-pervading auspiciousness and welfare of the world, so to serve him means serving to whole humankind, his interest means the interest of all. Following a visionary Ideal makes ourselves visionaries as mentioned in the central scripture of Satsang, Satyanusaran, The Pursuit of Truth:

"As is the ideal in whom you place faith, So will your nature be formed and Your vision too will be like that."

Although every human possesses the God-given conscience, the power of discrimination between good and evil, right and wrong, etc., very often everyone uses it on his way to suit his circumstance due to the influence of passion-driven selfish thoughts consciously or unconsciously. But this unpredictable or deceptive actions or behaviour can be avoided if every human being is attached to his living Ideal as Sree Sree Thakur Anukulchandra mentioned this very categorically in this following message: 
"When the Ideal is awake in man he is active, agile, inquisitive, responsible, alert and tactful ; in a word, all faculties bloom and glow."

Imparting invaluable wisdom through life transforming discourses, extremely detail scientific Holy scriptures and self-development meditation practices based on Sree Sree Thakur Anukulchandra's spiritual insights can make an ordinary life a celebration of human existence. In His lifetime, more than twenty-two thousands of pages of divine messages uttered from His holy mouth about how every human being and its environment could become more prosperous in all aspects of life. These collections of thoughts and ideas of Sree Sree Thakur Anukulchandra are a wealth of wisdom and could be used to find the solutions to any challenges faced by current and future generations.

\section{Convergence, Conversion and Initiation}

Sree Sree Thakur promoted the convergence of religion through Satsang, the Religion of convergence, founded by Himself. He mentioned convergence is better than conversion.

\section{According to Him conversion means:}

"Conversion ever diverts traditional trail with denial of former Advents-

the leading Masters of becoming,

but convergence makes all united and inter-interested

and makes them keep up the inter-unison of the Prophets according to the ages

with progressive run of life creating fellow-feeling from man to man."

In other discussions He mentioned that conversion means some type of verbal allegiance towards a specific religion in an enticement to fulfil the passion tinted complex after disregarding original connection with libido (libido is best translated by 'craving'). But in convergence, prophet according to the ages can provide the formula for leading a good life for man to man and woman to woman and can unite all inter-interested. 
Like all the past prophets' Sree Sree Thakur promoted fulfilling initiation rather than conversion. Initiation is a rite of passage marking entrance or acceptance into a group or society. In an extended sense it can also signify a transformation in which the initiate is 'reborn' into a new role. Examples of initiation ceremonies might include Hindu diksha, Christian baptism or confirmation, Jewish bar or bat mitzvah, acceptance into a fraternal organization, secret society or religious order. A person taking the initiation ceremony in traditional rites, such as those depicted in these pictures, is called an initiate. A person taking the initiation ceremony in traditional rites, such as those depicted in these pictures, is called an initiate. A spiritual initiation rite is normally a shepherding process where those who are at a higher level guide the initiate through a process of greater exposure of knowledge. This may include the revelation of secrets, hence the term secret society for such organizations, usually reserved for those at the higher level of understanding. An initiation can also be considered to cause a fundamental process of change to begin within the person being initiated and its evolution operates within both the material world and the spiritual world. The person conducting the initiation (the initiator), being in possession of a certain power or state of being, transfers this power or state to the person being initiated. Initiation is a key component of Judaism, Sufism, Vaishnavism, and similar religious gnostic traditions.

According to Satsang principles, fulfilling initiation is the acceptance of a Superior Beloved as a living ideal of an individual out of love for the existential survival and growth. It denotes acceptance by the Guru and it also implies that the disciple or initiated person agrees to certain requirements such as living an ethical life, meditating, etc. Satsang initiation does not compel initiated persons to leave the past traits, leave the existing Guru, leave the culture, rather it fulfils all the past traits which have been acquired over the generations in the form of the prophet of time. Satsang initiation is completely different from religious conversion. While religious conversion promotes renunciation of past traits, Satsang initiation promotes adherence with all the past traits along with the most vital attachment with prophet of the age. Any existing religion practitioner (Christian, Muslim, Jew, Sikh or Hindu) can take initiation of Satsang in the creed of Sree Sree Thakur Anukulchandra and can practice Satsang meditation whilst maintaining the traditional religious practices. Hence Satsang is a religion of convergence.

\section{Regarding importance of initiation, Jesus says in the Bible:}

"Verily, verily, I say unto thee. Except a man be born of water and of the Spirit, he cannot enter into the Kingdom of God."

Jesus described the process of baptism in terms of 'born of water and the Spirit'. In other words, unless someone is baptised, he cannot enter into the Kingdom of God.

In the similar context, Sree Sree Thakur mentioned the term 'Dwijikaran'. It is a Sanskrit word, which means the second birth following initiation of Superior Beloved i.e. Satguru. 
About fulfilling initiation in the Bible:

"Every scribe, who has become disciple of the realm of heaven is like a house-holder, who produces what is new and what is old from his stores."

That means, a person who is initiated in the creed of most fulfilling Ideal, the One who has got the knowledge of all the past prophets along with the knowledge of all current age problems.

Similarly, during discussions with some of His prominent Muslim devotees including Mohamed Khalilar Rahaman Sree Sree Thakur put forward the Ideas of complete eradication of Sectarian Conflict.

The meaning of the word 'Islam' in Arabic means the complete surrender to Superior Beloved and obedience to His law.

\section{According to the Holy Quran,}

"The religion of Islam is as wide in its conception as humanity itself. It didn't originate from the preaching of the Holy Prophet Muhammad, but it was equally the religion of the prophets who went before him. Islam was the religion of every prophet of God who appeared in any part of the world."

If we understand the meaning of Islam correctly, then we can understand that it is nothing but the religion of survival and growth. Sree Sree Thakur Anukulchandra has advocated the same principles.

Regarding adopting fulfilling initiation and accepting Him:

'If you love Allah (God), then follow me, Allah will love you'

From the sayings above, one can acknowledge that all the prophets in the past and present always promoted the initiation in the creed of the then prophets to fulfil spiritual aspirations Although all these prophecies provided the religious guidance for most of the population in the world, but in practice existing world religions do not support religious convergence in any form. In recent times convergence movements among the various Christian groups have become popular in the US, but still it is not widely practiced in most of the parts of the world. 


\section{Satsang, the Religion of Convergence}

The current prophet, Sree Sree Thakur Anukulchandra has strongly--- promoted religious convergence. In the 1st paragraph of His only hand-written book Satyanusaran, The Pursuit of Truth, He mentioned:

"Oh Mankind! If you desire to invoke your good, forget sectarian conflict. Be regardful to all the past Prophets. Be attached to you living Master or God and take only those who love Him as your own. Because all the past Prophets are consummated in the divine Man of the present"

For this reason, people from all faiths including Christians, Hindus and Muslims came to Him and accepted Him as their realised Guide, Guru and living Ideal, without diluting their identities. Whenever any Muslim, Christian and Hindu came to Him, He always preached them to be true a Muslim, true Christian, and a true Hindu. Although Satsang is one of the newest religions founded by Sree Sree Thakur Anukulchandra, but it is one of the fastest growing religions in the world. At present Satsang has more than 80 million members across the world, these members come from all walks of life and all major faiths of the world including Hinduism, Christianity, Islam and Atheism.

\section{Conclusion}

In summary, it is certainly in the interest of every individual, irrespective of faith, religion, race and nationality to explore the life and teachings of Sree Sree Thakur Anukulchandra and also to explore the doctrine of the new religion Satsang, in order to understand how religious convergence can be achieved practically among the believers of all the existing religions of the world, the pagans, the non-believers and the Atheists etc.

\section{Reference List}

1. Sree Sree Thakur Anukulchandra, 'Satyanusaran - The Pursuit of Truth' p 49

2. Sree Sree Thakur Anukulchandra, 'Satyanusaran - The Pursuit of Truth' $\mathrm{p} 1$

3. Sree Sree Thakur Anukulchandra, 'The Message Vol - II' p.115

4. Sree Sree Thakur Anukulchandra, 'The Message Vol - II' p.51 
5. Sree Sree Thakur Anukulchandra, 'The Message Vol - VI' p.49

6. Sree Sree Thakur Anukulchandra, 'The Message Vol - II' p.115

7. The Holy Bible John 3:5

8. The Holy Bible St.Mathew 14:51

9. Sree Sree Thakur Anukulchandra, 'The Discourses on Islam' p.21

Rajarshi Roy is an IT professional based in London. He has studied The Philosophies of Sree Sree Thakur Anukulchandra for more than 20 years. He visits various parts of UK and Europe extensively and deliver the speeches on the ideology and Philosophies of Sree Sree Thakur Anukulchandra. He organises Satsang Meditation sessions also regularly across UK and EU. 